\title{
Erythropoietin Therapy in Pre-Dialysis Patients with Chronic Renal Failure: Lack of Need for Parenteral Iron
}

\author{
Hariprasad S. Trivedia Blake J. Brooks ${ }^{b}$ \\ aNephrology Section, Harry S. Truman Memorial Veterans' Hospital, and 'bPost-Doctoral fellow, \\ Division of Nephrology, University of Missouri-Columbia, Columbia, Mo., USA
}

\section{Key Words}

Kidney failure - Chronic · Anemia - Erythropoietin .

Recombinant

\begin{abstract}
Background: During erythropoietin therapy, scant information exists regarding the optimal target percent saturation of transferrin (TSAT), ferritin and the mode and amount of iron supplementation in pre-dialysis patients with anemia due to chronic kidney disease (CKD). Hypothesis: Pre-dialysis CKD patients may have different needs for iron supplementation than end-stage renal disease subjects during erythropoietin therapy. Methods: Retrospective analysis of pre-dialysis CKD subjects ( $n=$ 31) treated with erythropoietin at our institution. Results: In this population our results showed that target hematocrit (33-36\%) was achievable with erythropoietin (mean subcutaneous dose $86 \pm 17$ [SD] units/kg/week) without parenteral iron therapy. The hematocrit increased from a mean baseline value of $28.4 \pm 2.7$ to $33.6 \pm 3.4 \%$ at time 1 (4-9 weeks, $p<0.0001$ ), and to $37.7 \pm 4.5 \%$ at time 2 (10-20 weeks, $p<0.0001$ ). The hemoglobin concentration increased from $9 \pm 0.9 \mathrm{~g} / \mathrm{dl}$ at baseline to $10.7 \pm$ $1.1 \mathrm{~g} / \mathrm{dl}$ at time $1(\mathrm{p}<0.0001)$ and to $12 \pm 1.5 \mathrm{~g} / \mathrm{dl}$ at time $2(p<0.0001)$. Subgroup analyses of patients prescribed
\end{abstract}

$<200 \mathrm{mg}$ oral elemental iron per day $(n=10)$, those with TSAT $<20 \%$ and/or ferritin $<100 \mathrm{ng} / \mathrm{ml}(\mathrm{n}=19)$, and those prescribed erythropoietin $<80$ units $/ \mathrm{kg} /$ week $(n=12)$, all showed a significant increase in hematocrit and hemoglobin. Conclusions: Our data show that pre-dialysis CKD subjects respond adequately to erythropoietin at or lower than recommended erythropoietin doses without parenteral iron. This response extends even to subgroups with TSAT and/or ferritin levels deemed to indicate iron deficiency in CKD subjects, and may be due to lack of existence of functional iron deficiency in this group of patients.

Copyright @2003 S. Karger AG, Basel

\section{Introduction}

There is no controversy regarding the premise that sufficient iron stores are required in order to achieve an adequate response to erythropoietin in patients with anemia due to chronic kidney disease (CKD) [1, 2]. Further, the rate of release of iron from storage sites in the reticuloendothelial system should be able to keep pace with the erythropoietin-driven increase in the need of the amount of iron delivered to the erythyroid precursors. Though accurate prediction of iron stores in end-stage renal dis-

\section{KARGER}

Fax + 41613061234 E-Mail karger@karger.ch www. karger.com
(C) 2003 S. Karger AG, Basel

0250-8095/03/0232-0078\$19.50/0

Accessible online at:

www. karger.com/ajn
Hariprasad Trivedi, MD

Nephrology Section, Harry S. Truman Memorial Veterans Hospital

800 Hospital Drive, Columbia, MO 65201 (USA)

Tel. +1 573882 4141, pager 564, Fax +1 5738146600

E-Mail trivedih@health.missouri.edu 
ease (ESRD) patients is difficult, serum ferritin and the percent saturation of transferrin (TSAT) are most useful for this purpose [2, 3]. The current National Kidney Foundation Dialysis Outcome Quality Initiative (NKFK/DOQI) Clinical Practice guidelines recommend that TSAT should be maintained $\geq 20 \%$ and serum ferritin $\geq 100 \mathrm{ng} / \mathrm{ml}$ in order to achieve adequate hemoglobin and hematocrit levels in CKD subjects receiving erythropoietin therapy [2]. It is critical to note that the term CKD, as defined by NKF-K/DOQI Anemia Work Group, encompasses the entire spectrum of chronic renal failure - predialysis, ESRD, and subjects with chronic allograft dysfunction [2]. In CKD patients absolute iron deficiency is said to exist when ferritin levels are $<100 \mathrm{ng} / \mathrm{ml}$ and TSAT is $<20 \%$ [2]. If ferritin is $<100 \mathrm{ng} / \mathrm{ml}$ and/or TSAT is $<20 \%$, intravenous iron loading is recommended for hemodialysis (HD) patients by the NKF-K/DOQI Anemia Work Group [2]. However, scant data exists regarding the need for parenteral iron loading and the optimal TSAT and ferritin in pre-dialysis patients with anemia due to renal failure, during erythropoietin therapy. Our experience suggests that there is little need for parenteral iron replacement in pre-dialysis CKD subjects receiving erythropoeitn. In this retrospective analysis we report our experience showing that in pre-dialysis CKD subjects target hematocrit (33-36\%) can be achieved, at or below the recommended weekly subcutaneous dosage ( $\leq 120$ units/ $\mathrm{kg} /$ week) without parenteral iron therapy.

\section{Materials and Methods}

A retrospective medical record review of pre-dialysis CKD subjects initiated on erythropoietin therapy at our institution for anemia of CKD from 1996 through 2001 was performed. Patients were selected for therapy based on clinical indications as determined by their treating physician. The computerized prescription record system used at our institution allowed identification of all patients prescribed erythropoietin during this time period.

The baseline hematocrit and hemoglobin were compared to values obtained at a visit scheduled after about 6 weeks (range 4-9 weeks - time 1) and about 3 months (range 10-20 weeks - time 2) after starting erythropoietin. If two values near or surrounding the specified time frame were available the mean value was used. Other parameters recorded included red blood cell indices, serum ferritin, and TSAT. Other information recorded included demographic characteristics, diagnosis, and the amount of oral iron prescribed. Patients prescribed erythropoietin at doses exceeding 120 units $/ \mathrm{kg} /$ week (rounded to nearest multiple of 5 units $/ \mathrm{kg} /$ week) were excluded from analysis since, arguably, the therapeutic response (if present) could have been to due the administration of dosage higher than recommended by the NKF-K/DOQI Anemia Work Group [2]. All complete blood counts (hematocrit, hemoglobin and red cell indices) were measured using an automated cell counter.

Erythropoietin Therapy for Pre-Dialysis

Chronic Renal Failure Subjects
Approval was obtained from the local Institutional Review Board, to conduct the retrospective medical record review.

\section{Statistical Methods}

Paired variables were analyzed using the paired t test or Wilcoxon signed rank test, as apposite. Unpaired continuous variables were analyzed using the unpaired t test or Wilcoxon Mann-Whitney test, as indicated. Categorical variables were analyzed using the Fisher exact test or chi-square test, as indicated. All analyses were 2-tailed and a $\mathrm{p}$ value $\leq 0.05$ was considered significant. Values are expressed as mean \pm standard deviation (SD).

\section{Results}

There were 30 males and 1 female with a mean age of $66.5 \pm 13.2$ years, mean pre-treatment serum creatinine of $4.3 \pm 1.7 \mathrm{mg} / \mathrm{dl}$ and mean baseline calculated creatinine clearance [4] of $22.9 \pm 11 \mathrm{ml} / \mathrm{min}$. The distribution of the etiology of CKD was diabetes mellitus $(n=15)$, obstructive nephropathy $(n=4)$, chronic interstitial nephritis $(n=4)$, focal segmental glomerulosclerosis $(n=1)$, crescentic glomerulonephritis $(\mathrm{n}=1)$, and unknown $(\mathrm{n}=$ 6). At baseline, the average mean corpuscular volume was $91.9 \pm 7.8 \mathrm{fl}$ and the mean corpuscular hemoglobin was $29 \pm 2.3 \mathrm{pg}$. Iron studies (ferritin and/or TSAT) were measured in all patients. The mean pre-erythropoietin ferritin was $217.6 \pm 184.2 \mathrm{ng} / \mathrm{ml}$ (1 missing value) and the mean TSAT was $19.8 \pm 11.4 \%$ (four missing values).

The hematocrit increased from a mean baseline value of $28.4 \pm 2.7$ to $33.6 \pm 3.4 \%$ at time $1(\mathrm{p}<0.0001$ for comparison with baseline), and to $37.7 \pm 4.5 \%$ at time 2 $(\mathrm{p}<0.0001$ for comparison with baseline and time 1 values) (fig. 1). The hemoglobin concentration increased from $9 \pm 0.9 \mathrm{~g} / \mathrm{dl}$ at baseline to $10.7 \pm 1.1 \mathrm{~g} / \mathrm{dl}$ at time 1 ( $\mathrm{p}<0.0001$ for comparison with baseline), and to $12 \pm$ $1.5 \mathrm{~g} / \mathrm{dl}$ at time $2(\mathrm{p}<0.0001$ for comparison with baseline and time 1 values) (fig. 1). For four patients only time 1 values were available due to starting dialysis therapy $(\mathrm{n}=$ 3) or stopping erythropoietin due to hematocrit far exceeding target $(n=1)$. All of these subjects had achieved target by time 1 . Overall sixteen $(51.6 \%)$ patients had achieved target values by time 1 . Eighteen patients (58\%) patients reached hematocrit levels meriting reduction in dosage of erythropoietin (defined as hematocrit exceeding target) and $45.2 \%$ patients had either a dose reduction $(32.3 \%)$ or discontinuation of erythropoietin (16.1\%). Twenty-one patients were prescribed about $200 \mathrm{mg}$ oral elemental iron per day $(67.7 \%)$ while the reminder were prescribed a lesser amount $(\mathrm{n}=10,32.3 \%)$. The mean weekly erythropoietin dose was $86 \pm 17$ units $/ \mathrm{kg}$ subcutaneously, in two to three divided doses.

Am J Nephrol 2003;23:78-85 
Fig. 1. Mean \pm SD hematocrit and hemoglobin, baseline through time $2 ; * \mathrm{p}<0.0001$ compared to baseline; $* * \mathrm{p}<0.0001$ compared to baseline and time 1 values.

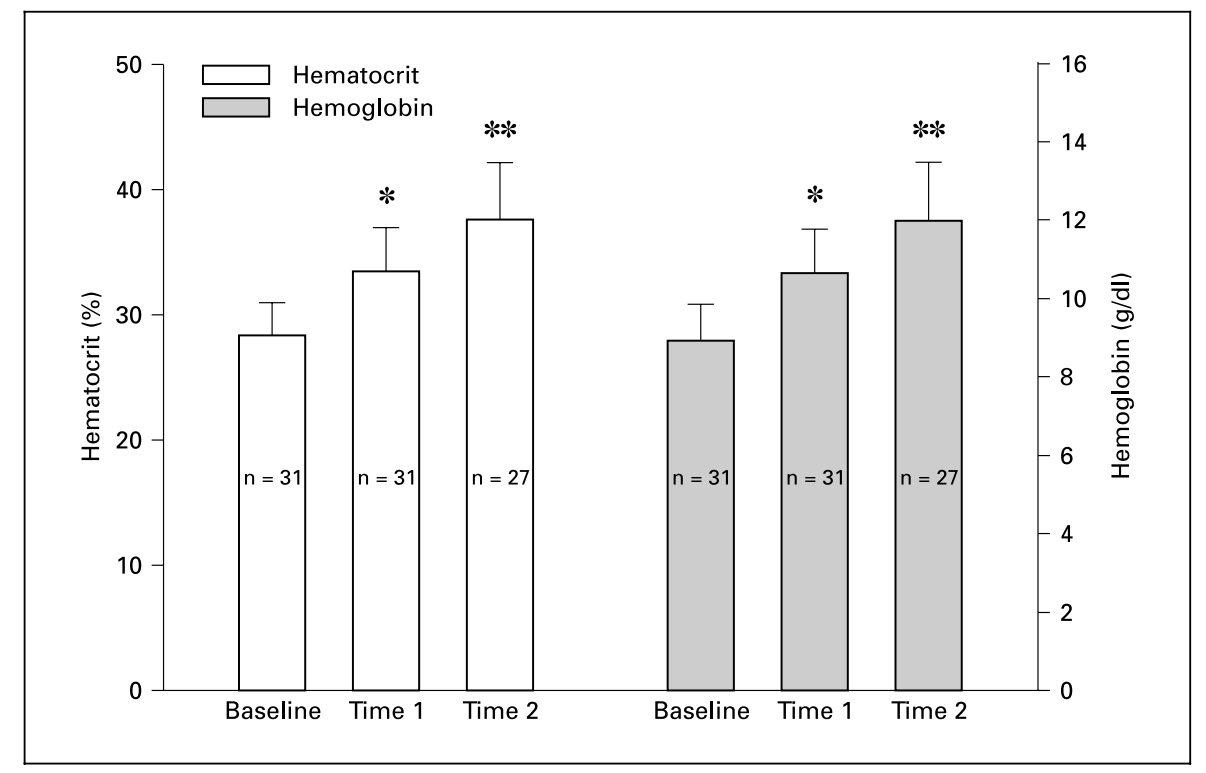

Fig. 2. Lines represent mean \pm SD hematocrit (left) and hemoglobin (right) of subjects prescribed $<200 \mathrm{mg}$ elemental iron per day; baseline to time 1 (solid line) baseline to time 2 (broken line); baseline vs. time 1, $* \mathrm{p}=0.0001$ for hematocrit, $* * * \mathrm{p}<0.0001$ for hemoglobin; baseline vs. time $2, * * \mathrm{p}=$ 0.0005 for hematocrit, $* * * * p=$ to 0.0009 for hemoglobin. Bars depict change in hematocrit (left) and hemoglobin (right) for subjects prescribed $<200 \mathrm{mg}$ iron (black bars) vs. subjects prescribed $200 \mathrm{mg}$ iron (grey bars), $\mathrm{p}>0.15$ for comparison between groups.

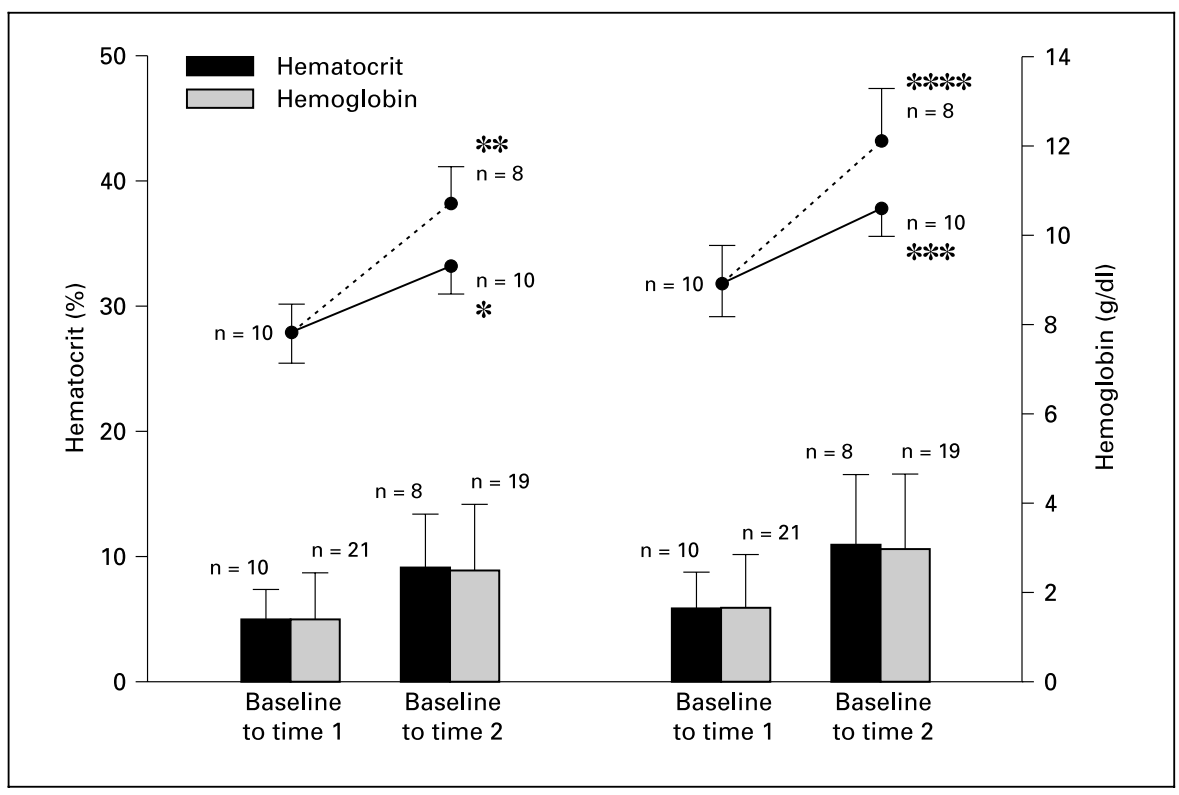

One patient could not be included due to lack of availability of the relevant clinical records. Seven patients were excluded due to prescription of higher than recommended erythropoietin doses, due to provider-dependent reasons, all of whom responded adequately without parenteral iron. The results were more impressive, showing a better response to erythropoietin without parenteral iron, if these subjects were included in the analysis (data not shown).

Analysis of subjects prescribed $<200 \mathrm{mg}$ oral elemental iron per day also showed a significant rise of hematocrit from baseline to time 1 (mean $28 \pm 2.3$ vs. $33 \pm 1.9 \%$, $\mathrm{p}=0.0001$ ) and baseline to time 2 (time 2 mean $37.7 \pm$ $3.6 \%, p=0.0005$ for comparison with baseline) (fig. 2). In this subgroup there was a similar significant rise hemoglobin from baseline to time 1 (mean $9 \pm 0.8$ vs. $10.6 \pm$ $0.6 \mathrm{~g} / \mathrm{dl}, \mathrm{p}<0.0001$ ), and baseline to time 2 (time 2 mean $12.1 \pm 1.2 \mathrm{~g} / \mathrm{dl}, \mathrm{p}=0.0009$ for comparison with baseline) (fig. 2). Between patients who were prescribed $<200 \mathrm{mg}$ elemental iron per day vs. those who were prescribed $200 \mathrm{mg}$ elemental iron there was no significant difference between the change in the hematocrit from baseline to 
Table 1. Serial hematocrit (\%) for patients with TSAT $<20 \%$ and/or ferritin $<100 \mathrm{ng} / \mathrm{ml}$

\begin{tabular}{|c|c|c|c|c|}
\hline & $\begin{array}{l}\text { Baseline } \\
\text { (pre-erythropoietin) }\end{array}$ & $\begin{array}{l}\text { Time } 1 \\
\text { [p vs. baseline] }\end{array}$ & $\begin{array}{l}\text { Time } 2 \\
\text { [p vs. baseline] }\end{array}$ & $\begin{array}{l}\text { Erythropoietin } \\
\text { dosage } \\
\text { (units } / \mathrm{kg} / \text { week) }\end{array}$ \\
\hline $\begin{array}{l}\text { TSAT }<20 \% \text { and/or } \\
\text { ferritin }<100 \mathrm{ng} / \mathrm{ml}\end{array}$ & $\begin{array}{l}28.5 \pm 2.6 \\
(n=19)\end{array}$ & $\begin{array}{l}34.2 \pm 3.7 \\
(\mathrm{n}=19) \\
{[\mathrm{p}<0.0001]}\end{array}$ & $\begin{array}{l}36.9 \pm 4.6 \\
(n=16) \\
{[p<0.0001]}\end{array}$ & $85.3 \pm 18.4$ \\
\hline $\begin{array}{l}\text { TSAT }<20 \% \text { and } \\
\text { ferritin }<100 \mathrm{ng} / \mathrm{ml}\end{array}$ & $\begin{array}{l}27.9 \pm 3.5 \\
(n=7)\end{array}$ & $\begin{array}{l}33.6 \pm 4.2 \\
(n=7) \\
{[p=0.016]}\end{array}$ & $\begin{array}{l}35.5 \pm 4.7 \\
(n=6) \\
{[p=0.0016]}\end{array}$ & $85.9 \pm 21.8$ \\
\hline $\begin{array}{l}\text { TSAT }<20 \% \text { or } \\
\text { ferritin }<100 \mathrm{ng} / \mathrm{ml}\end{array}$ & $\begin{array}{l}28.8 \pm 2 \\
(n=12)\end{array}$ & $\begin{array}{l}34.6 \pm 3.6 \\
(n=12) \\
{[p=0.0005]}\end{array}$ & $\begin{array}{l}37.7 \pm 4.6 \\
(n=10) \\
{[p=0.0001]}\end{array}$ & $85 \pm 17.2$ \\
\hline TSAT $<20 \%$ & $\begin{array}{l}28.7 \pm 2.6 \\
(\mathrm{n}=17)\end{array}$ & $\begin{array}{l}34.8 \pm 3.4 \\
(\mathrm{n}=17) \\
{[\mathrm{p}=0.000015]}\end{array}$ & $\begin{array}{l}37.1 \pm 4.8 \\
(n=14) \\
{[p<0.0001]}\end{array}$ & $86.4 \pm 19.1$ \\
\hline Ferritin $<100 \mathrm{ng} / \mathrm{ml}$ & $\begin{array}{l}27.6 \pm 3.1 \\
(\mathrm{n}=9)\end{array}$ & $\begin{array}{l}32.7 \pm 4.3 \\
(n=9) \\
{[p=0.0019]}\end{array}$ & $\begin{array}{l}35.6 \pm 4.2 \\
(n=8) \\
{[p=0.0001]}\end{array}$ & $83.6 \pm 19.5$ \\
\hline
\end{tabular}

time 1 ( $5 \pm 2.5$ vs. $5.3 \pm 3.6 \% ; \mathrm{p}=0.69)$ or baseline to time $2(9.2 \pm 4.3$ vs. $9 \pm 5.2 \% ; p=0.93)$, respectively (fig. 2). Similarly, between these two groups, there was no significant difference in the change in hemoglobin from baseline to time $1(1.7 \pm 0.8$ vs. $1.7 \pm 1.2 \mathrm{~g} / \mathrm{dl} ; \mathrm{p}=0.74)$ or baseline to time $2(3.1 \pm 1.6$ vs. $3 \pm 1.7 \mathrm{~g} / \mathrm{dl} ; \mathrm{p}=0.97)$ (fig. 2). It should be noted that, for the former comparisons, though there is inadequate statistical power to detect a difference of $25 \%$ with a power of 0.8 , at time 2 the mean change in hematocrit and hemoglobin is higher in the subgroup of patients who received $<200 \mathrm{mg}$ elemental iron per day. The mean erythropoietin dose for was also similar $87.8 \pm 18.6$ vs. $85.4 \pm 17.3$ units $/ \mathrm{kg} /$ week $(\mathrm{p}=$ 0.73 ). Between patients prescribed $<200 \mathrm{mg}$ oral elemental iron per day and those prescribed about $200 \mathrm{mg}$ elemental iron per day there was no difference in the number of patients who achieved target hematocrit (100 vs. $95.2 \%$ respectively, $\mathrm{p}=1$ for comparison between groups) or the need for reduction in erythropoietin dosage (60 vs. $61.2 \%$ respectively, $\mathrm{p}=1$ for comparison between groups). Note: $200 \mathrm{mg}$ elemental iron implies a 325-mg tablet of ferrous sulphate three times a day each containing $65 \mathrm{mg}$ elemental iron.

Three patients received no oral iron and all reached target hematocrit during the study period at a mean erythropoietin dose of $68.5 \pm 5.3$ units $/ \mathrm{kg} /$ week. Four patients who received $<200 \mathrm{mg}$ elemental iron per day had either a
TSAT $<20 \%$ and/or ferritin $<100 \mathrm{ng} / \mathrm{ml}$. During study period all reached target hematocrit at a mean erythropoietin dose of $93 \pm 21$ units $/ \mathrm{kg} /$ week. In this subset there was a statistically significant rise of hematocrit from baseline (mean $28.5 \pm 2.5)$ to time $2(38.1 \pm 0.6 \%, p=0.02$ for comparison, [only time 1 value available for 1 patient due to initiation of dialysis therapy]). For hemoglobin, too, the rise was significant from baseline to time 2 (time 2 mean $12.3 \pm 0.9, \mathrm{p}=0.01$ ).

A separate analysis was performed for the following subgroups - (A) subjects who had either ferritin $<100 \mathrm{ng} /$ $\mathrm{ml}$ and/or TSAT $<20 \%$ (one or both values below range), (B) ferritin $<100 \mathrm{ng} / \mathrm{ml}$ and TSAT $<20 \%$ (both values below range), (C) ferritin $<100 \mathrm{ng} / \mathrm{ml}$ or TSAT $<20 \%$ (any one value below range), (D) TSAT alone $<20 \%$, and (E) ferritin alone $<100 \mathrm{ng} / \mathrm{ml}$. For each of these subgroups there was a significant increase in hematocrit and hemoglobin from baseline to time 1 and baseline to time 2 (see tables 1 and 2 for actual values and corresponding erythropoietin dosages).

In subgroup B (subjects with ferritin $<100 \mathrm{ng} / \mathrm{ml}$ and TSAT $<20 \%$ ) one patient was prescribed $65 \mathrm{mg}$ elemental iron per day. The subject achieved a hematocrit $35.1 \%$ and hemoglobin $11.2 \mathrm{~g} / \mathrm{dl}$ at an erythropoietin dose of 104 units $/ \mathrm{kg} /$ week by time 1 , after which the patient began dialysis therapy. A second patient in this subgroup was prescribed $130 \mathrm{mg}$ elemental iron per day and an erythro- 
Fig. 3. Mean \pm SD hematocrit and hemoglobin for patients who received erythropoietin $<80$ units $/ \mathrm{kg} /$ week; $* \mathrm{p}<0.0001$ for baseline vs. time 1 hematocrit; $* * p<0.0001$ for baseline vs time 2 hematocrit; *** $\mathrm{p}<$ 0.0015 for baseline vs. time 1 hemoglobin; $* * * * \mathrm{p}=0.0004$ for baseline vs. time 2 hemoglobin.

Table 2. Serial hemoglobin (g/dl) for patients with TSAT $<20 \%$ and/or ferritin $<100 \mathrm{ng} / \mathrm{ml}$

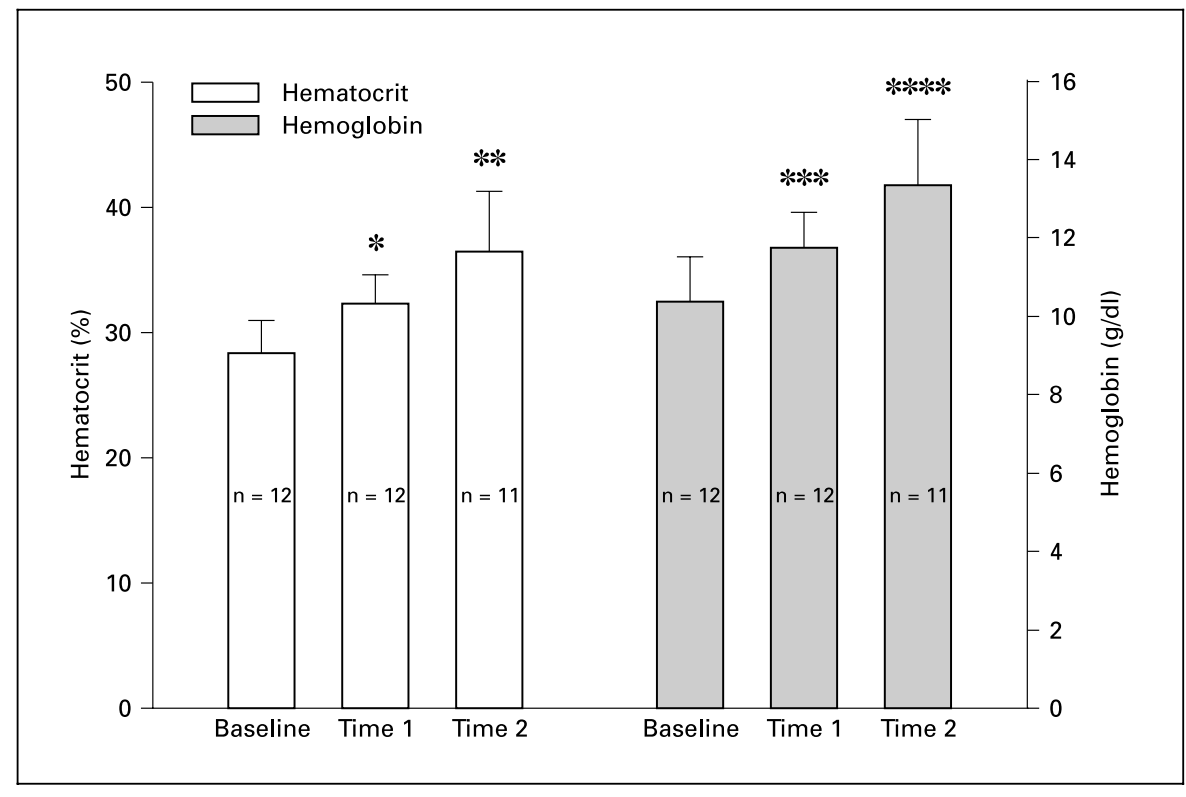

\begin{tabular}{|c|c|c|c|}
\hline & $\begin{array}{l}\text { Baseline } \\
\text { (pre-erythropoietin) }\end{array}$ & $\begin{array}{l}\text { Time } 1 \\
\text { [p vs. baseline] }\end{array}$ & $\begin{array}{l}\text { Time } 2 \\
\text { [p vs. baseline] }\end{array}$ \\
\hline $\begin{array}{l}\text { TSAT }<20 \% \text { and } / \text { or } \\
\text { ferritin }<100 \mathrm{ng} / \mathrm{ml}\end{array}$ & $\begin{array}{l}9 \pm 0.9 \\
(\mathrm{n}=19)\end{array}$ & $\begin{array}{l}10.8 \pm 1.2 \\
(\mathrm{n}=19) \\
{[\mathrm{p}<0.0001]}\end{array}$ & $\begin{array}{l}11.8 \pm 1.6 \\
(\mathrm{n}=16) \\
{[\mathrm{p}<0.0001]}\end{array}$ \\
\hline $\begin{array}{l}\text { TSAT }<20 \% \text { and } \\
\text { ferritin }<100 \mathrm{ng} / \mathrm{ml}\end{array}$ & $\begin{array}{l}9 \pm 1.1 \\
(\mathrm{n}=7)\end{array}$ & $\begin{array}{l}10.6 \pm 1.2 \\
(n=7) \\
{[p=0.012]}\end{array}$ & $\begin{array}{l}11.5 \pm 1.4 \\
(\mathrm{n}=6) \\
{[\mathrm{p}=0.004]}\end{array}$ \\
\hline $\begin{array}{l}\text { TSAT }<20 \% \text { or } \\
\text { ferritin }<100 \mathrm{ng} / \mathrm{ml}\end{array}$ & $\begin{array}{l}9.1 \pm 0.8 \\
(\mathrm{n}=12)\end{array}$ & $\begin{array}{l}11 \pm 1.3 \\
(\mathrm{n}=12) \\
{[\mathrm{p}<0.0001]}\end{array}$ & $\begin{array}{l}11.9 \pm 1.7 \\
(\mathrm{n}=10) \\
{[\mathrm{p}=0.0001]}\end{array}$ \\
\hline TSAT $<20 \%$ & $\begin{array}{l}9.1 \pm 0.9 \\
(\mathrm{n}=17)\end{array}$ & $\begin{array}{l}11.1 \pm 1.1 \\
(\mathrm{n}=17) \\
{[\mathrm{p}<0.0001]}\end{array}$ & $\begin{array}{l}11.9 \pm 1.6 \\
(\mathrm{n}=14) \\
{[\mathrm{p}<0.0001]}\end{array}$ \\
\hline Ferritin $<100 \mathrm{ng} / \mathrm{ml}$ & $\begin{array}{l}8.8 \pm 1 \\
(\mathrm{n}=9)\end{array}$ & $\begin{array}{l}10.3 \pm 1.3 \\
(\mathrm{n}=9) \\
{[\mathrm{p}=0.0047]}\end{array}$ & $\begin{array}{l}11.3 \pm 1.3 \\
(\mathrm{n}=8) \\
{[\mathrm{p}=0.0002]}\end{array}$ \\
\hline
\end{tabular}

poietin dose of 79.8 units $/ \mathrm{kg} /$ week. This patient achieved hematocrit of $37.6 \%$ and hemoglobin $12.7 \mathrm{~g} / \mathrm{dl}$ at time 2 .

Sub-analyses of subjects who received initial erythropoietin dose $<80$ units $/ \mathrm{kg} /$ week also showed a significant increase in hematocrit from baseline through time 2 (28.4 $\pm 2.6 \%$ at baseline, $32.4 \pm 2.3 \%$ at time 1 and $36.6 \pm$ $4.8 \%$ at time $2 ; \mathrm{p}<0.0001$ for baseline vs. time $1, \mathrm{p}=$ 0.0002 for comparison of baseline vs. time 2 , and $\mathrm{p}=$
0.0074 for comparison of time 1 vs. time 2 values) (fig. 3). In this sub-group there was also a significant increase in hemoglobin from baseline through time $2(9.1 \pm 1 \mathrm{~g} / \mathrm{dl}$ at baseline, $10.3 \pm 0.8 \mathrm{~g} / \mathrm{dl}$ at time 1 and $11.7 \pm 1.5 \mathrm{~g} / \mathrm{dl}$ at time 2; $p<0.0015$ for baseline vs. time $1, p=0.0004$ for comparison of baseline vs. time 2 , and $p=0.0075$ for comparison of time 1 values vs. time 2 values) (fig. 3 ). 
In the entire study only one patient did not achieve target hematocrit by time 2 ( 3 months) and was subsequently given parenteral iron therapy. After that, the patient immediately began ESRD therapy and hence whether parenteral iron made any difference in the responsiveness to erythropoietin, in the pre-dialytic phase, could not be assessed.

\section{Discussion}

The most important finding in our study is that in predialysis subjects with $\mathrm{CKD}$ an adequate response to erythropoietin can be achieved without parenteral iron therapy. This extends even to patients deemed to be iron deficient by currently used criteria in CKD subjects [2]. In our study, various subgroup analyses of subjects with different combinations of TSAT $<20 \%$ and/or ferritin $<100 \mathrm{ng} /$ $\mathrm{ml}$ all showed adequate response to erythropoietin without parenteral iron (tables 1 and 2). Even though the subgroups are small, the rise of hematocrit and hemoglobin was statistically significant and adequate.

The target hematocrit levels were well within the recent NKF-K/DOQI clinical practice guidelines (fig. 1) [2]. Moreover, subgroup analysis of patients who received $<200 \mathrm{mg}$ elemental iron per day, the minimum recommended dosage for oral iron replacement [2], showed that even this group achieved adequate hematocrit and hemoglobin levels (fig. 2). This suggests that during erythropoietin treatment iron needs of pre-dialysis CKD patients are much less and different than those of ESRD subjects. A European study, with a mean follow up of 5.2 months, that compared two different regimens of maintenance iron therapy in pre-dialysis CKD subjects, daily $600 \mathrm{mg}$ ferrous sulphate or equivalent orally (amount of elemental iron not given) vs. $300 \mathrm{mg}$ parenteral iron monthly, found no difference in response to erythropoietin in spite of higher ferritin levels in the parenteral group [5]. Intravenous iron therapy is not without risks, involves not insignificant labor, cost and inconveniences and could lead to reluctance on the part of the physician or patient in starting erythropoietin therapy. The long-term effects of iron therapy are unknown and there is experimental evidence that suggests that iron may play an adverse role in the progression of renal disease [6]. Further, intravenous iron therapy for pre-dialysis patients is limited by problems of reimbursement by third-party payers, based on existing practices. Given the results showing improvement in quality of life, survival and morbidity with proper treatment of anemia in CKD patients [2], the data are reassuring and should lead to a greater number of patients receiving erythropoietin therapy without the necessity of intravenous iron.

During erythropoietin therapy, in most instances, HD subjects with ferritin $<100 \mathrm{ng} / \mathrm{ml}$ and/or TSAT $<20 \%$, will require administration of parenteral iron. In such instances the Anemia Work Group recommends the administration of eight to ten consecutive doses of 100 $125 \mathrm{mg}$ each [2]. In pre-dialysis CKD subjects with such values, 500-1,000 mg intravenous iron has been suggested as a single infusion [2]. Our data suggest that, at the present time, TSAT $<20 \%$ and/or ferritin $<100 \mathrm{ng} / \mathrm{ml}$ should not be used to determine the need for parenteral loading iron in pre-dialysis $\mathrm{CKD}$ subjects receiving erythropoietin (tables 1 and 2).

The significant and adequate response observed in subjects with TSAT $<20 \%$ and ferritin $<100 \mathrm{ng} / \mathrm{ml}$, levels deemed to indicate iron deficiency in CKD subjects [2], without parenteral iron, is provocative and merits some discussion. One possibility is that oral iron was sufficient to provide the necessary iron for erythropoiesis. However, in such case one would have to conclude that iron absorption was sufficient to override existing iron deficiency (as currently defined in CKD subjects [2]) and provide sufficient iron to prevent the development of functional deficiency during erythropoietin therapy. This appears an unlikely scenario given the known limitation of gastrointestinal iron absorption. Analyses of subjects prescribed $<200 \mathrm{mg}$ iron showed a significant rise in hematocrit and hemoglobin by time 1 , by which time it is unlikely that a sufficient amount of oral iron would have been absorbed (fig. 2). Further, there was no difference in the change in hematocrit or hemoglobin (fig. 2) or erythropoietin dosage between patients who received about $200 \mathrm{mg}$ elemental iron per day versus those that received none or a lesser amount, again suggesting that increase in oral iron absorption was not responsible for the gratifying response.

Another possibility is that the criteria for functional and absolute iron deficiency for ESRD subjects are not applicable to pre-dialysis CKD subjects and need further study. It should be noted that iron deficiency is diagnosed in non-renal-failure subjects when ferritin is $<14 \mathrm{ng} / \mathrm{dl}$ (or below the lower limit set by the laboratory) [7]. It is possible that pre-dialysis CKD subjects behave similar to nonrenal-failure subjects with respect to iron kinetics. In a comparative study of erythropoietin response in ESRD subjects and normal individuals, a similar hematologic response was achieved in ESRD subjects, but with much higher iron stores reflected by much higher ferritin and TSAT [8]. Simply put, normal individuals required much 
lower iron stores to achieve a similar response, implying a much lower need for iron [8], and it is possible that predialysis CKD subjects behave similarly.

A third possibility is that ESRD subjects, especially HD patients, have a greater need for iron due to the higher inherent inflammatory state that leads to a state of functional iron deficiency. Numerous trials in ESRD subjects have shown that even with ferritin $>100 \mathrm{ng} / \mathrm{ml}$ and/or TSAT $>20 \%$, intravenous iron results in improvement in response to erythropoietin [2]. Functional iron deficiency defines a situation whereby the rate of release of iron from adequate iron stores in the reticuloendothelial system does not keep up with the erythropoietin-driven erythropoiesis, leading to a greater need for iron [2]. A wealth of data has demonstrated that chronic renal failure is an inflammatory state, even in the absence of clinically overt inflammatory pathology [9-20]. Further, recent literature suggests that this inflammatory state is a progressive spectrum, progressing with the progression of renal failure [10, $14,17]$. This state is highest in HD subjects, in part due to exposure to the dialysis membrane or antigen exposure via the dialysate, leading to activation of the acute phase response [11, 14, 18, 21-25]. Inflammatory markers are known to play a major role in the anemia of chronic disease. In this process, inflammatory cytokines prevent release of iron from mononuclear cells, leading it to be 'trapped', and thus while iron stores are normal or even high the amount of iron available for hemoglobin synthesis is low [26]. Cytokines such as interleukin-1, tumor necrosis factor, interferon-beta and interferon-gamma suppress proliferation of erythroid precursors and erythropoietin production $[2,27]$. Existing data supports this possibility, specifically the relation of the inherent inflammatory state of chronic renal failure to the anemia of renal failure, need for iron, and relative resistance to erythropoietin $[11,20,22,23,28-31]$. CKD sera, from patients without overt inflammation, suppress erythropoiesis due to stimulation of inflammatory cytokines such as interferon-gamma and tumor necrosis factor-alpha, the same cytokines invoked in inflammatory anemia [27, 32]. If this premise were true, pre-dialysis CKD subjects being at the earlier spectrum of the inflammatory process may have lesser or no functional iron deficiency and lesser need for iron. It is apparent that this intriguing possibility needs to be validated by stronger data, specifically a prospective correlation of markers of inflammation and the need for iron during erythropoietin therapy in CKD subjects.

Further, based on our results, it appears that pre-dialysis CKD subjects have a lesser erythropoietin dose re- quirement that ESRD subjects. Subgroup analyses of our subjects that received a weekly dose of erythropoietin less than the lower limit recommended by the NKF-K/DOQI Anemia Work Group guidelines (80 units $/ \mathrm{kg} /$ week), showed a significant and adequate rise of hemoglobin and hematocrit (fig. 3). A lower dose requirement for pre-dialysis CKD subjects has also been noted prospectively [5]. It should be pointed out that previous dose finding and efficacy studies (phase 1-3) evaluated intravenous erythropoietin administration in $\operatorname{HD}[33,34]$. Subsequently a significant amount of literature regarding subcutaneous use in ESRD subjects is available [2], with scant data in predialysis patients. Due to lack of data, it appears that experience with subcutaneous dose in ESRD subjects has been extended to CKD patients in general, without it being possible to make a distinction between pre-dialysis and ESRD subjects [2]. Till data from dose-finding studies specifically in pre-dialysis subjects with CKD are available, based on our experience it may be prudent to start therapy at lower doses, $50-80 \mathrm{units} / \mathrm{kg} /$ week, in this group of patients.

It is pertinent to note that the study carries with it the limitations common to retrospective analyses. It is conceivable that some would-be non-responders were inadvertently not offered erythropoietin therapy based on personal practices of the treating physician(s), creating a potential selection bias. However, the large proportion of responders, the extent of the gratifying response and the ability to identify all patients prescribed erythropoietin in the study period suggests that these factors are unlikely to negatively influence the overall results. Further only one female subject was included in the study, the demographics being typical of a Veterans' Affairs hospital. Hence the results may not be applicable to female patients unless more data is forthcoming in this group of subjects. It is critical to note that the results of the study can only be considered to be applicable to the initial 3- to 4-month period of erythropoeitin therapy, the time frame of our analyses. Further study is required to assess if the same results can be maintained, without parenteral iron, after a longer duration, e.g. 6-12 months. However, it is clear that a distinction is warranted in the recommendations for iron therapy and erythropoietin dosage in ESRD subjects vs. pre-dialysis CKD subjects. Whether parenteral iron loading, i.e. an infusion of 500-1,000 mg as suggested by NKF-K/DOQI Anemia Work Group [2] will result in improvement in response to erythropoietin and further decrease in the dosage requirement needs to be evaluated in a prospective randomized manner. 
To conclude, our data show that pre-dialysis CKD subjects respond adequately to erythropoietin at or lower recommended erythropoietin doses without parenteral iron. This extends even to patients conventionally thought to be iron deficient by conventional criteria applied to CKD subjects.

\section{Acknowledgements}

This manuscript is the result of work supported with resources and the use of facilities at the Harry S. Truman Memorial Veterans' Hospital, Columbia, Mo., USA. The authors acknowledge Harold Moore, MS for creation of the figures and Karl Nolph, MD for reviewing the manuscript.

\section{References}

1 NKF-DOQI Clinical Practice guidelines for the treatment of anemia of chronic renal failure. New York, National Kidney Foundation, 1997, pp 15-16.

2 National Kidney Foundation. K/DOQI Clinical Practice guidelines for Anemia of chronic kidney disease, 2000. Am J Kidney Dis 2001; 37(suppl 1):S182-238

3 Fishbane S, Maesaka JK: Iron management in end-stage renal disease. Am J Kidney Dis 1997; 29:319-333.

4 Cockcroft DW, Gault MH: Prediction of creatinine clearance from serum creatinine. Nephron 1976;16:31-41.

5 Stoves J, Inglis H, Newstead CG: A randomized study of oral vs intravenous iron supplementation in patients with progressive renal insufficiency treated with erythropoietin. Nephrol Dial Transplant 2001;16:967-974.

6 Shah S: Role of iron in progressive renal disease. Am J Kidney Dis 2001;37(suppl 2):S30 S33.

7 Bridges KR, Bunn FH: Anemias with disturbed iron metabolism; in Isselbacher KJ, Martin JB, Braunwald E, Fauci AS, Wilson JD, Kasper DL (eds): Harrison's Principles of Internal Medicine, ed 13. New York, McGraw-Hill, 1994, pp 1721-1726.

8 Eschbach JW, Haley NR, Egrie JC, Adamson JW: A comparison of responses to recombinant human erythropoietin in normal and uremic subjects. Kidney Int 1992;42:407-416.

9 Arici M, Walls J: End-stage renal disease, atherosclerosis, and cardiovascular morbidity: is C-reactive protein the missing link? Kidney In 2001:59:407-414

10 Descmaps-Latscha B, Witko-Sarsat V: Importance of oxidatively modified proteins in chronic renal failure. Kidney Int 2001;suppl 78:S103-113

11 Stenvinkel P: The role of inflammation in the anemia of end-stage renal disease. Nephrol Dial Transplant 2001;16(suppl 7):36-40.

12 Mezzano D, Pais EO, Aranda E, Panes O, Downey P, Ortiz M, Tagle R, Gonzalez F, Quiroga $\mathrm{T}$, Caceres MS, Leighton $\mathrm{F}$, Pereira $\mathrm{J}$ : Inflammation, not hyperhomocysteinemia, is related to oxidative stress and hemostatic dysfunction in uremia. Kidney Int 2001;60:18441850 .

13 Zoccali C, Benedetto FA, Mallamaci F, Tripepi G, Fermo I, Foca A, Paroni R, Malatino LS Inflammation is associated with carotid atherosclerosis in dialysis patients. Creed Investigators. Cardiovascular risk extended evaluation in dialysis patients. J Hypertens 2000;18: 1207-1213.
14 Panichi V, Migliori M, De Pietro S, Taccola D, Bainchi AM, Norpoth M, Giovannini L, Palla $\mathrm{R}$, Tetta C: C-reactive protein as a marker of chronic inflammation in uremic patients. Blood Purif 2000;18:183-190.

15 Stenvinkel P, Heimburger O, Paultre F, Diczfalusy $\mathrm{U}$, Wang $\mathrm{T}$, Berglund $\mathrm{L}$, Jogestand $\mathrm{T}$ : Strong association between malnutrition, inflammation, and atherosclerosis in chronic renal failure. Kidney Int 1999;55:1899-1911.

16 Bistrian BR: Role of systemic inflammatory response syndrome in the development of protein-calorie malnutrition in ESRD. Am J Kidney Dis 1998;32(suppl 4):S113-117.

17 Witko-Sarsat V, Friedlander M, Nguyen Khoa T, Capeillere-Blandin C, Nguyen AT, Canteloup S, Dayer JM, Jungers P, Drueke T, Descamps-Latscha B: Advanced oxidation endproducts as novel mediators of inflammation and monocyte activation in chronic renal failure. J Immunol 1998;161:2524-2532.

18 McIntyre C, Harper I, Macdougall IC, Raine AE, Wiliams A, Baker LR: Serum C-reactive protein as a marker for infection and inflammation in regular dialysis patients. Clin Nephrol 1997;48:371-374.

19 Bolton $\mathrm{CH}$, Downs LG, Victory JG, Dwight JF, Tomson CR, Mackness MI, Pinkney JH Endothelial dysfunction in chronic renal failure: roles of lipoprotein oxidation and proinflammatory cytokines. Nephrol Dial Transplant 2001;16:1189-1197.

20 Cassidy MJ, De Jager C, Ebrahim O, Camachio P, Robson S: Peripheral blood monocytes cells form patients with chronic renal failure release factors which suppress erythropoietin production in vitro. Nephrol Dial Transplant 1994:9:775-779.

21 Schindler R, Linnenweber S, Schulze M, Oppermann M, Dinarello CA, Shaldon S, Koch KM: Gene expression of interleukin-1 beta during hemodialysis. Kidney Int 1993;43:712_ 721.

22 Sitter T, Bergner A, Schiffl H: Dialysate related cytokine induction and response to human erythropoietin in haemodialysis patients. Nephrol Dial Transplant 2000;5:1207-1211.

23 Kaysen GA: Inflammation nutritional state and outcome in end stage renal disease. Miner Electrolyte Metab 1999;25:242-250.

24 Pertosa G, Marfella C, Tarantino EA, Di Cillo M, Manno C, Russo R, Schena FP: Involvement of peripheral blood monocytes in haemodialysis: in vivo induction of tumour necrosis factor alpha, interleukin 6, and beta 2-microglobin. Nephrol Dial Transplant 1991;6(suppl 2):18-23.
25 Ryan JJ, Beynon HL, Rees AJ, Cassidy MJ: In vitro production of tumor necrosis factor by monocytes cultured from dialysis patients. Kidney Int 1993;suppl 41:S226-S229.

26 Bunn FH: Anemia associated with chronic disorders; in Isselbacher KJ, Martin JB, Braunwald E, Fauci AS, Wilson JD, Kasper DL (eds) Harrison's Principles of Internal Medicine, ed 13. New York, McGraw-Hill, 1994, pp 1732 1734.

27 Hillman RS: Iron deficiency and other hypoproliferative anemias; in Fauci AS, Braunwald E, Isselbacher KJ, Wilson JD, Martin JB, Kasper DL, Hauser SL, Longo DL (eds): Harrison's Principles of Internal Medicine, ed 14. New York, McGraw-Hill, 1998, pp 638-645.

28 Gunnell J, Yeun JY, Depner TA, Kaysen GA: Acute-phase response predicts erythropoeitin resistance in hemodialysis and peritoneal dialysis patients. Am J Kidney Dis 1999;33:6372.

29 Owen WF, Lowrie EG: C-reactive protein as an outcome predictor for maintenance hemodialysis patients. Kidney Int 1998;54:627-636.

30 Barany P, Divino FJC, Bergstrom J: High Creactive protein is a strong predictor of resistance to erythropoietin in hemodialysis. Am J Kidney Dis 1997;29:565-568.

31 Bovy C, Tsobo C, Crapanzano L, Rorive G, Beguin Y, Albert A, Paulus JM: Factors determining the percentage of hypochromic red blood cells in hemodialysis patients. Kidney Int 1999;53:1113-1119.

32 Allen DA, Breen C, Yaqoob MM, Macdougal IC: Inhibition of CFU-E colony formation in uremic patients with inflammatory: role of IFN-gamma and TNF-alpha. J Investig Med 1999;47:204-211.

33 Eschbach JW, Egrie JC, Downing MR, Browne JK, Adamson JW: Correction of the anemia of end-stage renal disease with recombinant human erythropoietin: Results of a combined phase I and II clinical trial. N Engl J Med 1987; 316:73-78.

34 Eschbach JW, Abdulhadi MH, Browne JK, Delano BG, Downing MR, Egrie JC, Evans RW, Friedman EA, Graber SE, Haley NR, Korbet S, Krantz SB, Lundin AP, Nissenson AR, Ogden DA, Paganini EP, Rader B, Rutsky EA, Stivelman J, Stone WJ Teschan P, Van Stone JC, Van Wyck DB, Zuckerman K, Adamson J: Recombinant human erythropoietin in anemic patients with end-stage renal disease. Results of a phase III multicenter clinical trial. Ann Intern Med 1989;111:992-1000. 